\title{
Erratum to Gibson (2017) On the nature and origin of garnet in highly-refractory Archean lithospheric mantle: constraints from garnet exsolved in Kaapvaal craton orthopyroxenes (Mineralogical Magazine, 81, 781-809).
}

In Gibson (2017) a number of reconstructed analyses have been mis-calculated affecting Table 4, Fig. 7 and some mentions in the text.

Page 781 - There is also a mistake in the Abstract. In the final sentence the word "stability" should be replaced by "instability". The correct version is: "Such a process would considerably increase the density and instability of the continental lithosphere."

Page 792 - A corrected Fig. 7 is now:

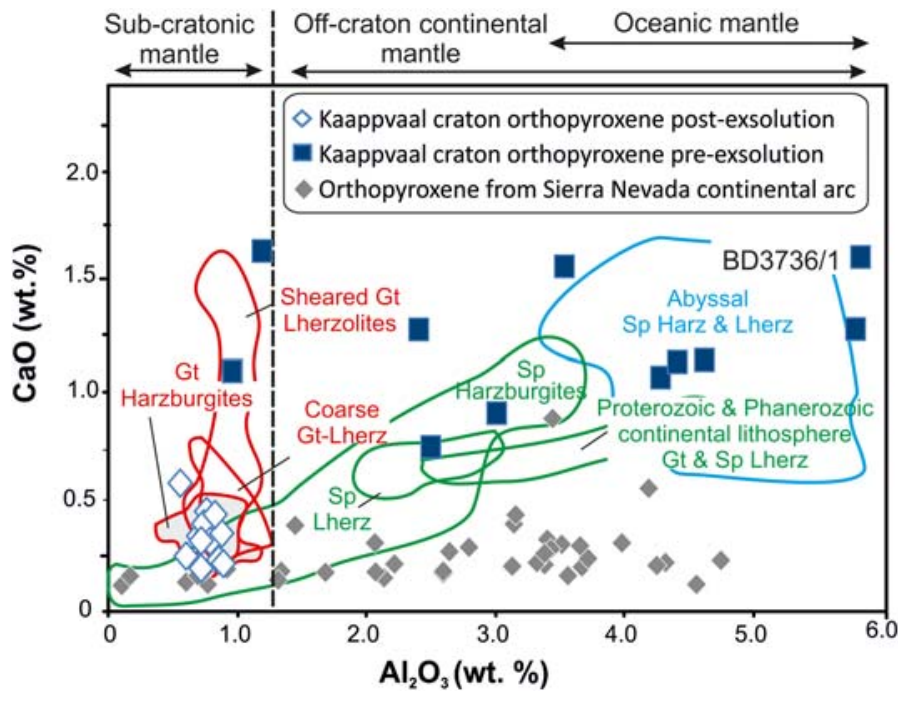

FIG. 7.

Page 797 - Table 4 with the last six columns corrected is shown overleaf.

Page 793 - under the heading "Reconstructed primary orthopyroxene compositions" the text "Mg\# (82 to 93), $\mathrm{Al}_{2} \mathrm{O}_{3}$ (1.0 to 5.8 wt.\%) and $\mathrm{CaO}$ contents ( 0.9 to $\left.1.7 \mathrm{wt} . \%\right)$ " should be replaced with "Mg\# (82 to 93 ), $\mathrm{Al}_{2} \mathrm{O}_{3}$ (1.0 to 5.8 wt.\%) and $\mathrm{CaO}$ contents $(0.9$ to 1.7 wt.\%)" and "Table 1" with "Table 2" to give: "The 


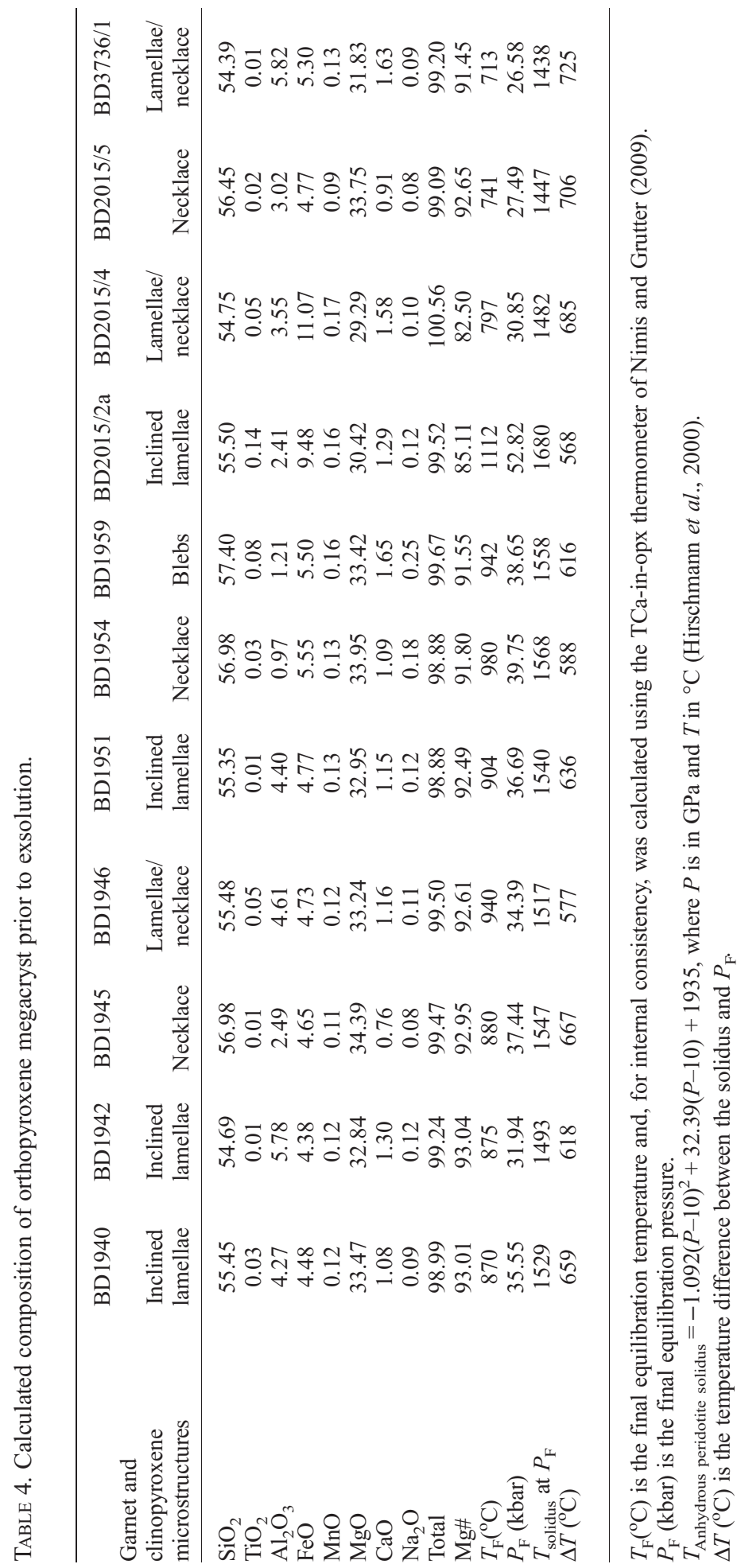


pre-exsolution megacryst compositions all have the correct stoichiometry for orthopyroxene but they are highly variable in terms of $\mathrm{Mg} \#$ ( 82 to 93$), \mathrm{Al}_{2} \mathrm{O}_{3}$ (1.0 to $\left.5.8 \mathrm{wt} . \%\right)$ and $\mathrm{CaO}$ contents ( 0.9 to $\left.1.7 \mathrm{wt} . \%\right)$. It is noteworthy that the $\mathrm{Mg \#}$ of both the reconstructed pre-exsolution orthopyroxene (Table 4) and postexsolution orthopyroxene megacrysts (Table 2) are similar and do not appear to have changed during exsolution. This is consistent with the findings of von Seckendorff and O'Neill (1993) which showed that the $\mathrm{Fe} / \mathrm{Mg}$ ratio in orthopyroxene is controlled by bulk-rock composition and relatively insensitive to changes in temperature and pressure. In contrast to $\mathrm{Mg} \#$, the contents of both $\mathrm{CaO}$ and $\mathrm{Al}_{2} \mathrm{O}_{3}$ are noticeably greater (Fig. 7) and the $\mathrm{SiO}_{2}$ content is lower in the pre-exsolution orthopyroxene."

Page 801 - the text "they are similar" should be replaced by "some are similar" and "Mg\# (91-94) with Mg\# (91-93)" to give: "Exceptions are the recalculated, pre-exsolution compositions of orthopyroxene megacrysts from Frank Smith mine which have high $\mathrm{CaO}$ for a given $\mathrm{Al}_{2} \mathrm{O}_{3}$ content; in this respect some are similar to orthopyroxenes found in metasomatized and sheared, high-temperature garnet peridotites (lherzolites, Fig. 7). The high Mg\# (91-93) estimated for the preexsolution ...."

Page 802 - the text "Mg\# =92.6" should be replaced by "Mg\# =92.4" to give: "The higher Mg\# of the Kaapvaal orthopyroxenes (mean Mg\# $=92.4$, excl. Frank Smith mine) ...."

The above does not alter any of the other findings presented in the paper, apologies for any inconvenience this error has caused.

\section{SALLY GiBSON}

